\title{
The Singapore International Commercial Court: The Future of Litigation?
}

Man Yip*

\section{Abstract}

The Singapore International Commercial Court ('SICC') was launched on 5 January 2015, at the Opening of Legal Year held at the Singapore Supreme Court. What prompted the creation of SICC? How is the SICC model of litigation different from litigation in the Singapore High Court? What is the SICC's track record and what does it tell us about its future? This article seeks to answer these questions at greater depth than existing literature. Importantly, it examines these questions from the angle of reimagining access of justice for litigants embroiled in international commercial disputes. It argues that the SICC's enduring contribution to improving access to justice is that it helps to change our frame of reference for international commercial litigation. Hybridisation, internationalisation, and party autonomy, the underpinning values of the SICC, are likely to be the values of the future of dispute resolution. International commercial dispute resolution frameworks - typically litigation frameworks - that unduly emphasise national boundaries and formalities need not and should not be the norm. Crucially, the SICC co-opts a refreshing public-private perspective to the resolution of international commercial disputes. It illuminates on the public interest element of the resolution of such disputes which have for some time fallen into the domain of international commercial arbitration; at the same time, it introduces greater scope for self-determination in international commercial litigation.

Keywords: international commercial court, Singapore, dispute resolution, litigation

\section{Introduction}

The Singapore International Commercial Court (SICC) was launched on 5 January 2015 at the Opening of Legal Year, held at the Singapore Supreme Court, before a curious audience comprising both local and foreign lawyers. ${ }^{1}$ The SICC is not the first international commercial court that the world has seen. The famous Dubai

Man Yip, BCL (Oxon), manyip@smu.edu.sg This article analyses the SICC regime based on the legislative rules as of 1 November 2018.

1. A. See and M. Yip, 'Opening of Legal Year 2015: A Year for Pushing Boundaries', Singapore Law Blog, 6 January 2015, available at: http:// www.singaporelawblog.sg/blog/article/75 (last visited 8 February 2019).
International Financial Centre Courts (DIFCC) ${ }^{2}$ were established in 2004 to cater to the resolution of civil and commercial disputes arising from the special economic zone, the Dubai International Financial Centre. ${ }^{3}$ But the SICC is indubitably the first of its kind. It was not created to foster investor confidence by providing for a completely different system of administration of justice from the indigenous legal system. On the contrary, the SICC was established on the foundation of a mature and established legal system that investors already have confidence in. It was set in operation before the plans for establishing the international commercial courts in various European countries and China were formulated. What prompted the creation of SICC? How is the SICC model of litigation different from litigation in the Singapore High Court? What is the SICC's track record, and what does it tell us about its future?

This article seeks to answer these questions in greater depth than does the existing literature. Importantly, it examines these questions from the angle of reimagining access to justice for litigants embroiled in international commercial disputes. It argues that the SICC's enduring contribution to improving access to justice is that it helps to change our frame of reference for international commercial litigation. Hybridisation, internationalisation and party autonomy, the underpinning values of the SICC, are likely to be the values of the future of dispute resolution. International commercial dispute resolution frameworks - typically litigation frameworks - that unduly emphasise national boundaries and formalities need not and should not be the norm. Crucially, the SICC co-opts a refreshing public-private perspective to the resolution of international commercial disputes. It illuminates the public interest element of the resolution of such disputes which have for some time fallen into the domain of international commercial arbitration; at the same time, it introduces a greater scope for self-determination in international commercial litigation.

The discussion comprises four main parts. The first part (Section 2) analyses the reasons for creating a Singaporean model of international commercial court at different levels: national interests, regional needs and

2. Dubai International Financial Centre Courts, 'About the DIFC Courts', available at: https://www.difccourts.ae/about-courts/ (last visited 8 February 2019).

3. The DIFCC's jurisdiction has expanded since to include jurisdiction in cases where parties have by written agreement submitted their disputes to the DIFCC, even if such disputes did not arise from activities in the Dubai International Financial Centre. 
public interests. The second part (Section 3) discusses the salient features of the SICC litigation framework, highlighting the innovations in relation to jurisdiction, procedures, panel of judges, and foreign legal experts' participation. The third part (Section 4) critically examines the judgments handed down by the SICC to date to extract emerging patterns. The final part (Section 5) discusses two potential challenges that the SICC faces: competition from the Chinese international commercial courts and the international enforceability of Singapore judgments.

\section{The Reasons for the Creation of the SICC}

The idea of creating a Singaporean model of international commercial court was first mooted by the chief justice of Singapore, Sundaresh Menon, at the Opening of Legal Year 2013. As he recounted extrajudicially, his visit to the London Commercial Court in September 2012 brought fresh insights into how to further invigorate the dispute resolution landscape in Singapore. In his words,

The London experience suggests that arbitration and commercial courts are not competing players in a zero-sum game. Rather, there is room for co-existence and development of these two systems of dispute resolution. ${ }^{4}$

While the inspiration for the SICC originated from the London Commercial Court, the success of the London Commercial Court alone does not explain the need to create a new litigation model in Singapore. After all, the London Commercial Court is very much a national court in design and operation. What Chief Justice Menon's account does clarify is that his vision for the Singapore landscape is based on the coexistence of both litigation and arbitration in the resolution of international commercial disputes. In this part, we will critically review the reasons for the creation of the SICC from different perspectives.

\subsection{National Interests}

Let us start with the Singapore perspective. Legal services can be a highly profitable industry. According to Mr Shanmugam, Minister for Home Affairs and Law of Singapore, the value of the legal services section had grown by $71.5 \%$ from 2008 to $2013 .{ }^{5}$ It should, thus,

4. S. Menon, 'International Commercial Courts: Towards a Transnational System of Dispute Resolution', 19 January 2015, at para. 10, available at: https://www.supremecourt.gov.sg/docs/default-source/defaultdocument-library/media-room/opening-lecture---difc-lectureseries-2015.pdf (last visited 8 February 2019).

5. Z. Hamzah, 'Positioning Singapore as Asia's Legal Capital', The Straits Times, 16 January 2015, available at: https://www.straitstimes.com/ opinion/positioning-singapore-as-asias-legal-capital (last visited 8 February 2019). In the same commentary, it was reported that the growth rate of Singapore's legal sector outstripped that of the overall economy. come as no surprise that investing in the expansion of the legal services industry - including the dispute resolution services subsector - would be a natural move to make. Nor was it coincidental that the Singapore International Mediation Centre (SIMC) and its training arm, the Singapore International Mediation Institute (SIMI), were launched in 2014. With a booming arbitration business sector helmed by the successful Singapore International Arbitration Centre (SIAC) ${ }^{6}$ the obvious initiative to take up would be invigorating the litigation services subsector. Singapore was gearing up to become the leading one-stop shop for dispute resolution. The SICC, the SIAC and the SIMC (in tandem with the SIMI) are the hallmarks of the nation's three-pronged strategy to become a premium dispute resolution hub through a comprehensive offering of dispute resolution services. Singapore's game plan is to augment the menu of dispute resolution options for potential users.

The next question is why a new court, as opposed to improving the existing one, namely the Singapore High Court, was created? Institutionally, there are two advantages of creating a new 'court'. First, a new litigation model provides a clean slate on which innovations may be made. Second, the creation of a nem litigation model is a marketing strategy to highlight Singapore's thought leadership in dispute resolution and, accordingly, build a brand image. From the user perspective, the creation of a new court, while retaining the traditional Singapore court, represents a choice between two systems of litigation. It signals to the potential users that autonomy in litigation services is an important value under Singapore law.

\subsection{Regional Needs?}

The prelaunch SICC feasibility study - the Report of the Singapore International Commercial Court Committee (SICC Committee Report) - states:

Cross border investment and trade into Asia and between Asian economies is expected to continue to grow, fuelling the need for a neutral and wellregarded dispute resolution hub in the region. ${ }^{7}$

The SICC Committee Report further points out that arbitration alone cannot fulfil that important role of providing satisfactory dispute resolution services:

Arbitration has thus far been the primary means of international commercial dispute resolution within the region, but its increasing currency has highligh-

6. In 2015, the year in which the SICC was launched, the SIAC received 271 cases from 55 jurisdictions, setting a new record for the highest number of cases filed since its commencement in 1991. See 'SIAC Announces Record Case Numbers for 2015', Singapore International Arbitration Centre, 25 February 2016, available at: http:// www.siac.org.sg/images/stories/press_release/SIAC\%20Announces \%20Record\%20Case \%20Numbers\%20for\%202015_25\%20February \%202016.pdf (last visited 8 February 2019).

7. Report of the Singapore International Commercial Court Committee, 29 November 2013, at para. 8, available at: https://www.mlaw.gov.sg/ content/dam/minlaw/corp/News/Annex\%20A\%20-\%20SICC \%20Committee\%20Report.pdf (last visited 8 February 2019). 
ted weaknesses that litigation in an international court is better placed to address - the coercive jurisdiction of a court may be necessary in a multiple party dispute; the subject matter of the dispute may not be amenable to arbitration (such as special torts arising from contract, international intellectual property or trust disputes); and the New York Convention, while wide in its reach, may not be fully effective for enforcement in some countries. ${ }^{8}$

A study on legal systems in the Association of SouthEast Asian Nations (ASEAN) in $2018^{9}$ highlighted that the domestic courts of a number of ASEAN countries adopt their indigenous language as the language of court proceedings, creating a language barrier for foreign litigants to access justice through litigation in the domestic courts. Further, litigation in domestic courts in a number of ASEAN countries is not favoured owing to perceptions of uncertainty, unpredictability in outcome, protracted processes and lack of judicial independence. As for arbitration, the study points out that there is a lack of judicial support for the recognition or enforcement of foreign arbitral awards in some ASEAN countries, even though some of these countries are Contracting States to the Convention on the Recognition and Enforcement of Foreign Arbitral Awards (New York, 1958) (New York Convention). The study also incorporates a survey component, one of whose findings is that slightly more than half of twenty-four respondents (businesses operating in ASEAN) saw the need for a 'new ASEAN-wide dispute resolution structure which specialises in hearing contract disputes between ASEAN businesses'. ${ }^{10}$

Incidentally, in the same year that Chief Justice Menon mooted the idea of establishing an international commercial court in Singapore, China announced its ambitious plan for the transnational 'One Belt, One Road' project, which is now simply known as the Belt and Road Initiative (BRI). Although the SICC Committee Report made no mention of the impact of BRI on the dispute resolution needs of the region, it is envisaged that the BRI will further increase the volume of commercial dealings between parties in the BRI countries and that disputes are, therefore, likely to increase in the coming years. For this reason, China launched two Chinese international commercial courts, one in Xi'an and the other in Shenzhen (the CICC), in June 2018 to serve the dispute needs of the BRI. A review of the CICC jurisdictional framework reveals that the CICC is not designed to take on all commercial disputes arising from the BRI. ${ }^{11}$ There is, therefore, a gap for the SICC to fill.

8. Id., at para. 16

9. L. Hsu, P. Koh \& M. Yip, 'Report: Improving Connectivity between ASEAN's Legal Systems to Address Commercial Issues', 22 March 2018, available at: https://www.canasean.com/reports/ (last visited 8 February 2019).

10. Id., at 105-6. See further P. Koh, 'Enhancing Economic Co-operation: A Regional Arbitration Centre for ASEAN?', 49 International and Comparative Law Quarterly 390 (2000)

11. M.S. Erie, 'The China International Commercial Court: Prospects for Dispute Resolution for the "Belt and Road Initiative"', 22(11) American
Although there is a regional need for a well-regarded and efficient dispute resolution institution, it is too early to tell whether SICC can fulfil that function. Challenges would include the international enforceability of Singapore judgments as well as competition from other institutions, including arbitration centres ${ }^{12}$ and other international commercial courts. We will look at these challenges in Section 5.

\subsection{Public Interests?}

The increasing popularity of using arbitration for the resolution of commercial disputes is affirmed by the Queen Mary University of London and White \& Case LLP 2018 International Arbitration Survey (QMUL International Arbitration Survey 2018) findings. ${ }^{13}$ Ninety-seven per cent of the respondents indicated international arbitration as their favoured dispute resolution mechanism, either as a stand-alone method or in combination with alternative dispute resolution (ADR). The perceived advantageous features of international arbitration, in descending order, are enforceability of awards, avoiding specific legal systems/national courts, flexibility, and ability of parties to select arbitrators. Ninetynine per cent of the respondents 'would recommend international arbitration to resolve cross-border disputes in the future'. ${ }^{14}$ In a survey conducted by the Singapore Academy of Law's International Promotion of Singapore Law Committee in 2016, arbitration similarly emerged as the preferred dispute resolution mechanism. $^{15}$

The advantages of arbitration notwithstanding, from a public interest standpoint, the fact that the arbitral proceedings and awards are confidential would mean that the application and development of commercial law are hidden from the world. ${ }^{16}$ As arbitral awards do not have a binding effect and the merits of the award are not open to review, there is no system of ensuring consistent application and development of commercial law in arbitral practice. While this may suit the parties inter se, a 'hidden from view' approach impedes the coherent development of commercial law. If the popularity of using arbitration continues, visible development of com-

Society of International Law Insights 1 (2018); Z. Huo and M. Yip, 'Comparing the International Commercial Courts of China with the Singapore International Commercial Court', International and Comparative Law Quarterly (2019, forthcoming).

12. For instance, the recently rebranded Asian International Arbitration Centre (formerly Kuala Lumpur Regional Centre for Arbitration) would be keen to compete for dispute business.

13. Queen Mary University of London and White \& Case LLP, '2018 International Arbitration Survey: The Evolution of International Arbitration', 2018, at 2, available at: http://www.arbitration.qmul.ac.uk/media/ arbitration/docs/2018-International-Arbitration-Survey---The-

Evolution-of-International-Arbitration.PDF (last visited 8 February 2019).

14. Ibid.

15. For a summary of the survey findings, see Singapore Academy of Law, 'Study on Governing Law \& Jurisdictional Choices in Cross-border Transactions', 11 January 2016, available at: http://www.ciarb.org.sg/ wp-content/uploads/2016/02/SAL_Singapore_Law_Survey.pdf (last visited 8 February 2019).

16. See generally C.A. Rogers, 'Transparency in International Commercial Arbitration', 54 Kansas Law Review 1301 (2006). 
mercial law (in the courts) will continue to decline. The merits of the common law system depend critically on a steady stream of cases to enable incremental development (including refinement or correction) of the law. Crucially, the arbitral outcomes do not only affect the commercial parties to the proceedings. The outcomes will necessarily generate downstream effects on other parties (e.g. the parties who would ultimately bear the costs of the decision or third parties related to the dispute but did not consent to participate in the same arbitration). Finally, the fact that arbitral proceedings are not subject to public scrutiny raised issues of accountability. ${ }^{17}$ According to the QMUL International Arbitration Survey 2018 findings, respondents 'think that arbitration rules should include provisions dealing with arbitrator conduct in terms of both standards of independence and impartiality and efficiency (or lack thereof)'. 18

In view of the foregoing concerns, there is a place for litigation. The practical question is the ways in which we can encourage commercial parties to choose litigation. In Section 3, we consider the innovative litigation framework of the SICC, which borrows from the arbitration template.

\section{The SICC Litigation Framework}

This part of the discussion reviews the innovative features of the SICC litigation framework, which may be broadly grouped into three categories: (a) jurisdiction; (b) procedural features and (c) international judges. All three aspects are critical to the delivery of justice.

To begin with an overview, the SICC was established as a division of the Singapore High Court. ${ }^{19}$ Within the Singapore judicial system, the Singapore Court of Appeal is the apex court. Below the Court of Appeal is the High Court, and below the High Court is the State Courts. ${ }^{20}$ The jurisdictional rules and procedural fea-

17. For instance, the arbitral practice of allowing party-appointed arbitrator has come under attack. See, e.g., S. Menon, 'Adjudicator, Advocate or Something in Between?: Coming to Terms with the Role of the Partyappointed Arbitrator', 24 November 2016, available at: http:// www.supremecourt.gov.sg/Data/Editor/Documents/CJ\%20speech \%20at\%20CIArb\%20Presidential\%20Lecture\%202016.pdf (last visited 8 February 2019).

18. Queen Mary University of London and White \& Case LLP, above n. 13, at 3. See generally D.H. Wong, 'The Rise of the International Commercial Court: What Is It and Will It Work?', 33 Civil Justice Quarterly 205, at 216-19 (2014)

19. To avoid confusion, any reference to the 'High Court' or 'Singapore High Court' henceforth shall refer to the Singapore High Court sans the SICC division, unless otherwise indicated. For a diagram of the court structure, see Singapore International Commercial Court, Overview of the SICC, available at: https://www.sicc.gov.sg/about-the-sicc/ overview-of-the-sicc (last visited 8 February 2019).

20. For a more detailed discussion of the structure and responsibilities of the Singapore judiciary, see G. Chan, 'The Judiciary', in G. Chan and J. Lee (gen. eds.), The Legal System of Singapore: Institutions, Principles and Practices (2015), at 155 tures of the SICC are set out in the Supreme Court of Judicature Act (SCJA) ${ }^{21}$ and the Rules of Court, a subsidiary legislation of the SCJA. ${ }^{22}$ As Singapore is a common law jurisdiction, the Singapore courts' interpretation and application of the legislative provisions - producing what may be described as a body of statute-based common law - is a binding source of law on the application of these legislative rules. Supplementing and clarifying the operation of the legislation are the SICC Practice Directions, ${ }^{23}$ the SICC User Guides ${ }^{24}$ and the SICC Procedural Guide. ${ }^{25}$ However, these supplementary materials ${ }^{26}$ are not formal sources of law.

\subsection{Jurisdiction Over International and Commercial Actions}

Existing literature has dealt extensively with the jurisdictional rules of the SICC from a private international law perspective. ${ }^{27}$ The present analysis shall instead focus on highlighting the innovations and how they have improved access to justice for litigants.

\subsubsection{Subject Matter Furisdiction}

The SICC hears 'international' and 'commercial' claims. ${ }^{28}$ The term 'international' is generally defined by reference to parties' places of business: if they are in different states; if neither is in Singapore; or if one party's place of business is in a different state from either the state in which a substantial part of the obligations arising from the parties' commercial relationship is to be performed or the state with which the subject matter of the dispute is most closely connected. ${ }^{29}$ Further, the definition 'international' allows parties to expressly agree that 'the subject matter of their claim relates to more than one State'. ${ }^{30}$

As for the meaning of 'commercial', a claim is considered 'commercial' if it arises from a commercial rela-

21. Supreme Court of Judicature Act, ch. 322 (2007) (SCJA).

22. Rules of Court, ch. 332, s. 80 (2014).

23. In this article, a reference to the 'SICC Practice Directions' shall refer to the version that is effective as of 1 November 2018.

24. Reference to the SICC User Guides in this article refers to the version as at 31 January 2019

25. These materials are available at: www.sicc.gov.sg (last visited 8 February 2019).

26. For instance, the SICC User Guides explicitly state that the contents are 'for reference purposes only' and are not 'binding on the [SICC]'. See https://www.sicc.gov.sg/docs/default-source/legislation-rules-pd/siccuser-guides-31jan19.pdf (last visited 10 February 2019).

27. See, e.g., T.M. Yeo, 'Staying Relevant: Exercise of Jurisdiction in the Age of the SICC', 13 May 2015, available at: http://law.smu.edu.sg/ sites/default/files/law/CEBCLA/YPH-Paper-2015.pdf (last visited 8 February 2019); M. Yip, 'The Resolution of Disputes before the Singapore International Commercial Court', 65 International and Comparative Law Quarterly 439 (2016); M. Yip, 'Navigating Singapore's Private International Rules in the Age of Innovative Cross-border Commercial Litigation Framework', in P. Sooksripaisarnkit and S.R. Garimella (eds.), China's One Belt One Road Initiative and Private International Law (2018) 55; A. Chong and M. Yip, 'Singapore as a Centre for International Commercial Litigation: Party Autonomy to the Fore', 15 Journal of Private International Law 97 (2019, forthcoming).

28. Section 18D(a) SCJA; Order 110, rule 7(1)(a) Rules of Court.

29. Order 110, rule 1(2)(a)(i)-(iii) Rules of Court.

30. Order 110, rule 1(2)(a)(iv) Rules of Court. 
tionship, ${ }^{31}$ if it pertains to an in personam intellectual property dispute or if parties have expressly agreed that the claim is commercial in character. ${ }^{32}$

A striking commonality of the statutory definitions for 'international' and 'commercial' is that it admits parties' agreement on the nature of the claim. From a policy perspective, this approach upholds the value of party autonomy. Pragmatically, this approach also relieved the Singapore legislature of the difficult task of laying down workable and comprehensive definitions. It implicitly acknowledges that the distinction between 'international' and 'domestic' as well as between 'commercial' and 'non-commercial' is not a bright-line exercise. The SICC approach is, thus, to favour characterising the claim as 'international' or 'commercial' in the first instance for the purpose of commencement of proceedings in the SICC by according to the parties the right of determination. Overly technical definitions are thereby avoided. As will become clear in the discussion later on the SICC's in personam jurisdictional rules, where the SICC suit was commenced pursuant to an SICC jurisdiction clause, the SICC may decline to assume jurisdiction on exceptional grounds, in particular, by considering the character of the claim before it. ${ }^{33}$

\subsubsection{Written Furisdiction Agreement}

There are two main ways in which international and commercial claims would come before the SICC. ${ }^{34}$ The first way is by the parties' submission to the SICC's jurisdiction through a written jurisdiction agreement. ${ }^{35}$

Consensual jurisdiction is a well-established basis of jurisdiction under Singapore law, even pre-SICC. What is novel is that even if the defendant is based abroad and service of legal process out of Singapore is therefore required, leave of court for extraterritorial service is not required. ${ }^{36}$ By contrast, under the traditional Singapore High Court procedural regime, even where the dispute arises out of a Singapore jurisdiction agreement, leave of court for service out of jurisdiction is mandated, ${ }^{37}$ save where there is a contractually stipulated mode of local service. ${ }^{38}$ This procedural liberalisation under the SICC framework implicitly recognises that the exercise of extraterritorial jurisdiction is not as 'exorbitant' as traditionally perceived to be $\mathrm{e}^{39}$ and that parties' choice alone

31. See Order 110, rule 1(2)(b)(i) Rules of Court for a non-exhaustive list of commercial relationships.

32. Order 110, rule 1(2)(b)(ii)-(iii) Rules of Court.

33. See text to $n .42$ below.

34. The third way arises exceptionally in cases involving 'an originating summons under Order 52 for leave to commit a person for contempt in respect of any judgment or order made by the Court': see Order 110, rule $7(2)(b)$ Rules of Court.

35. Order 110, rule 7(1)(b) Rules of Court. This is provided that parties are not seeking any form of prerogative relief: see Order 110 , rule $7(1)(c)$ Rules of Court. See Singapore International Commercial Court, SICC Model Clauses, available at: https://www.sicc.gov.sg/guide-to-thesicc/model-clauses (last visited 8 February 2019).

36. Order 110, rule 6(2) and (2A) Rules of Court.

37. Order 11, rule 1 Rules of Court.

38. Order 10, rule 3 Rules of Court.

39. Cf. Zoom Communications Ltd v. Broadcast Solutions Pte Ltd [2014] SGCA 44, [2014] 4 SLR 500, at para. 72. The Singapore Court of Appeal remarked (in a pre-SICC case) that the exercise of jurisdiction is a sufficient basis to establish existence of jurisdiction. In this day and age, given the ease of travel, technological advancement and the trend of globalisation, crossborder disputes are commonplace. Importantly, if a foreign defendant has agreed to submit to the jurisdiction of the SICC, there is little basis for him or her to complain about the inconvenience and costs associated with defending himself or herself in the SICC as these would generally be foreseeable at the time of contracting. Thus, in practice, the dispensation of court's leave to serve out of Singapore would save the plaintiff both costs and time.

Further, the SICC jurisdictional rules make clear that the SICC may decline to assume jurisdiction only if it is 'not appropriate' for the case to be heard by the SICC ${ }^{40}$ and that it may not do so on the sole ground that the claim is connected to a foreign forum. ${ }^{41}$ In considering the guiding criterion of 'not appropriate', the SICC shall have regard to the international and commercial character of the claim. ${ }^{42}$ While this approach is unremarkable insofar as an exclusive jurisdiction clause is concerned, ${ }^{43}$ it is remarkable where a non-exclusive jurisdiction clause is concerned, as the conventional test for forum appropriateness under Singapore law is in part based on an evaluation of connections with the competing fora. ${ }^{44}$

The overarching point is this: the parties' expression of choice in the form of a non-exclusive jurisdiction clause is accorded greater respect under the SICC framework than under the traditional High Court framework. On one view, this may be celebrated as a triumph of party autonomy over conservative forum regulation. Indeed, as will become apparent in subsequent discussion, the SICC operates on a more internationalised framework than traditional litigation. It is designed to hear cases

by the Singapore courts over a foreign defendant is, in a real sense, an imposition on him'

40. Order 110, rule 8(1) Rules of Court.

41. Order 110, rule 8(2) Rules of Court.

42. Order 110, rule 8(3) Rules of Court. For example, an apparent dispute between two companies may on closer scrutiny reveal that the background to the commercial dispute involves a husband and a wife - respectively, the sole shareholder and director of the companies embroiled in contentious ancillary divorce proceedings. The dispute is thus substantively a contest over (quasi) matrimonial assets. See IM Skaugen SE v. MAN Diesel \& Turbo SE [2016] SGHCR 6, at para. 112; Report of the Singapore International Commercial Court Committee, above n. 7, at para. 28.

43. Even in respect of proceedings before the Singapore High Court, the court would generally enforce the obligation to sue in the exclusively chosen forum, save where exceptional circumstance amounting to 'strong cause' can be shown to justify the breach of contract to sue in a non-chosen forum. Connections to a foreign forum are generally not considered exceptional circumstances. See Golden Shore Transportation Pte Ltd v. UCO Bank [2003] SGCA 43, [2004] 1 SLR(R) 6 at paras. 33 and 38.

44. Orchard Capital I Ltd v. Ravindra Kumar Jhunihunwala [2012] SGCA 16, [2012] 2 SLR 519, at para. 12. The non-exclusive jurisdiction clause is one of the factors in the discretionary analysis: at para. 30. Notably, the SICC Committee Report proposed reforming the forum non conveniens rules on which the SICC may decline to exercise jurisdiction in the context of a non-exclusive jurisdiction agreement. See Report of the Singapore International Commercial Court Committee, above n. 7, at para. 27. 
with foreign or international elements. In fact, the SICC framework recognises a category of cases known as 'offshore cases', that is, cases with no substantial connection to Singapore. ${ }^{45}$ As will be explained below, there is greater scope for procedural flexibility in this category of cases, in order to attract disputes that would not otherwise be heard in the Singapore courts. On another view, party autonomy is used as a means to favour the SICC hearing international commercial disputes. This view is bolstered by other pro-SICC provisions. For instance, unless there is provision to the contrary, a written jurisdiction agreement in favour of the SICC is considered to be exclusive in nature. ${ }^{46}$ For jurisdiction agreements entered into, on or after 1 October 2016, ${ }^{47}$ unless 'a contrary intention appears in the agreement', an agreement to submit to the jurisdiction of the Singapore High Court shall be construed as including an agreement to submit to the jurisdiction of the [SICC]'. ${ }^{48}$ While these pro-SICC provisions may be justified on pragmatic concerns to avoid uncertainty, it cannot be denied that the overall effect is to favour the SICC hearing the claims in dispute.

\subsubsection{Transfer Furisdiction}

A second main way by which disputes will come before the SICC is through the transfer of proceedings from the Singapore High Court to the SICC. ${ }^{49}$ The rules on transfer jurisdiction have been made more complex by Singapore's ratification of the Hague Convention on Choice of Court Agreements (Hague Convention). ${ }^{50}$ Pursuant to Order 110, rule 12(4) of the Rules of Court, a non-Hague Convention case may be transferred from the Singapore High Court to the SICC if the action concerns international and commercial claims; if the parties are not seeking any form of prerogative relief; it is more appropriate for the action to be heard in the SICC; and if all the parties consent to the transfer or the High Court orders the transfer on its own motion after hearing the parties. As for Hague Convention cases, Order 110 , rule $12(3 \mathrm{~B})$ provides for the same criteria, save that

45. See Order 110, rule 1(1) Rules of Court. However, an 'offshore case' does not include IAA proceedings commenced by way of originating summons and in rem actions (against a ship or any other property) under the High Court (Admiralty Jurisdiction) Act (Cap. 123). Order 110 , rule $1(2)(f)$ Rules of Court continues to specify that an action has no substantial connection to Singapore where Singapore law is not the governing law and the subject-matter of the dispute is not regulated by Singapore law; or if the only connections to Singapore are parties' choice of Singapore law as the governing law of the dispute and parties' submission to the SICC. In Teras Offshore Pte Ltd v. Teras Cargo Transport (America) LLC [2016] SGHC(I) 02, [2016] 4 SLR 75, at para. 8, Eder IJ explained that 'the question is not whether the action has a substantial connection with some place or places other than Singapore but whether the action has no substantial connection with Singapore'. He also clarified that some connections may be irrelevant or peripheral: at para. 16.

46. Sections $18 \mathrm{~F}(1)$ (a) and $18 \mathrm{~F}(2) \mathrm{SCJA}$.

47. The date on which the implementing legislation for the Hague Convention on Choice of Court Agreements entered into force in Singapore.

48. Order 110, rule 1(2)(ca) Rules of Court

49. Order 110, rule 7(2)(a) Rules of Court.

50. Hague Convention on Choice of Court Agreements, 30 June 2005, 44 ILM 1294, available at: https://www.hcch.net/en/instruments/ conventions/full-text/?cid=98 (last visited on 8 February 2019). the High Court may not order a transfer of proceedings on its own motion without having obtained all parties' consent. Although the level of consent required for transfer of proceedings differs under the two sets of rules, ${ }^{51}$ more generally, the rules on transfer jurisdiction oblige the Singapore High Court to have regard to parties' choice, even though parties' choice is not determinative of the outcome in non-Hague Convention cases under Order 110, rule 12(4).

The statutory rules do not clarify when it might be more 'appropriate' for a case to be heard in the SICC than in the High Court. In this connection, two recent Singapore cases may helpfully shed light on the possible interpretation of 'appropriate'. Both cases concerned a situation where the plaintiff argued for the case to be heard in Singapore but the defendant applied for a stay of proceedings in order that the case may be transferred to a foreign forum for resolution. The legal inquiry was whether it would be more appropriate for Singapore than a foreign forum to hear the dispute - that is, a question of international jurisdiction. In Rappo, Tania v. Accent Delight International Ltd, ${ }^{52}$ the Singapore Court of Appeal affirmed that ' $[\mathrm{t}]$ he presence of the SICC and its capabilities are potentially relevant to the [forum non conveniens] analysis', ${ }^{53}$ as the procedural features of the SICC may reduce costs or neutralise the advantages of having the case heard overseas. In the subsequent case of IM Skaugen SE v. MAN Diesel E Turbo SE, the Singapore High Court remarked that an 'archetypal dispute' that might be better dealt with by the SICC is one where the factual and legal connections are distributed across 'diverse and geographically divided' jurisdictions. ${ }^{54}$ Based on the foregoing, the overall tenor is that the SICC is especially suitable for dealing with cases with international elements, as they lend themselves to the SICC's unique capabilities. By extension, it may be argued that the characteristics of a claim and whether they lend themselves to the SICC's capabilities are relevant factors in determining whether it is more appropriate for the SICC, as compared with the High Court, to resolve the dispute ${ }^{55}$ - a question of internal jurisdiction. We will consider the capabilities of the SICC in Section 3.3.

\subsection{Jurisdiction Over International Commercial Arbitration Matters}

With effect from 1 November 2018, the SICC is conferred jurisdiction 'to hear any proceedings relating to international commercial arbitration that the High

51. The more stringent requirement of consent under Order 110, rule 12(3B) Rules of Court may be justified on the basis of ensuring a more straightforward process for the enforcement and recognition of the resulting judgment in other Contracting States: see Art. 8(5) Hague Convention. See explanation in Chong and Yip (2019), above n. 27.

52. [2017] SGCA 27, [2017] 2 SLR 265. In this case, the lower court urged the parties to consider a transfer of proceedings to the SICC: see Accent Delight International Ltd v. Bouvier, Yves Charles Edgar [2016] SGHC 40, [2016] 2 SLR 841, at paras. 111-16

53. Id., at para. 116 .

54. [2018] SGHC 123, at para. 216. This case is currently pending appeal.

55. See further Chong and Yip (2019), above n. 27. 
Court may hear and that satisfy such conditions as the Rules of Court may prescribe'. ${ }^{56}$ According to the Rules of Court, the only requirement in respect of the SICC's jurisdiction to hear international commercial arbitration matters is that the 'proceedings must be proceedings that the High Court may hear' under the International Arbitration Act (IAA) ${ }^{57}$ These applications include stay of proceedings, interim measures, challenges to arbitrators, challenges to awards, recognition and enforcement of awards, appeals on ruling of jurisdiction and subpoenas. The term 'international' in this context adopts the meaning set out in section 5(2) of the IAA; and the meaning of 'commercial' is to be guided by that provided in the UNCITRAL Model Law on International Commercial Arbitration. ${ }^{58}$ Further, IAA proceedings commenced in the High Court may be transferred to the SICC, pursuant to the requirements provided in Order 110 , rule 58 of the Rules of Court.

The expansion of the SICC's jurisdiction to hear international arbitration matters had been predicted 3 years ago, when the SICC was launched into operation. ${ }^{59}$ The parliamentary intention was to 'increase Singapore's attractiveness as a seat of arbitration', in part, through the enhanced appeal of the Singapore bench, which now includes international judges. ${ }^{60}$ This legislative reform iterates that the Singapore vision for its dispute resolution landscape is based on the coexistence of arbitration and litigation.

However, in line with the position in respect of IAA applications before the High Court, only Singaporequalified lawyers may appear before the SICC in respect of IAA applications. ${ }^{61}$ As such, the definition of an 'offshore' case $\mathrm{C}^{62}$ - matters in which the SICC will take a more generous approach in granting foreign representation - does not include IAA proceedings brought before the SICC. The exclusion of foreign representation in IAA proceedings was explained in the second reading of the bill in parliament: ${ }^{63}$

The IAA is part of Singapore law, with features that are tailored for the Singapore arbitration landscape,

56. Section $18 \mathrm{D}(2) \mathrm{SCJA}$. This provision was introduced pursuant to a bill passed by Singapore Parliament on 9 January 2018.

57. Cap 143A, Rev Ed 2002

58. Order 110, rule 57(2) Rules of Court. See, in particular, the meaning of 'commercial arbitration' set out in Order 110, rule 57(2)(c).

59. J. Ahmad and P. Tan, 'Should Court Actions Arising Out of International Arbitration Disputes Be Heard at the Singapore International Commercial Court', Kluwer Arbitration Blog, 17 July 2015, available at: http:// arbitrationblog.kluwerarbitration.com/2015/07/17/should-courtactions-arising-out-of-international-arbitration-disputes-be-heard-atthe-singapore-international-commercial-court/?print=pdf (last visited 8 February 2019)

60. 'Second Reading Speech by Ms Indranee Rajah, Senior Minister of State for Law and Finance, on Supreme Court of Judicature (Amendment) Bill', available at: https://www.mlaw.gov.sg/content/minlaw/en/news/ parliamentary-speeches-and-responses/second-reading-speechsupreme-court-of-judicature-bill.html (last visited 8 February 2019).

61. Ibid

62. See n. 45 above.

63. 'Second Reading Speech by Ms Indranee Rajah, Senior Minister of State for Law and Finance, on Supreme Court of Judicature (Amendment) Bill', above n. 60. and there is a developed body of local jurisprudence based on our Courts' interpretation and application of the IAA provisions, which Singapore lawyers are well versed in.

\subsection{Procedural Features}

The SICC has been described as 'a careful marriage between litigation and arbitration' ${ }^{64}$ In other words, it is a hybrid design, drawing from the advantageous features of both processes. This does not, however, mean that the SICC is the sum of the advantages of both processes. The hybridisation of litigation and arbitration inevitably results in a different mechanism. All in all, it may be said that the SICC procedural framework admits a greater scope for the consideration of parties' preferences than the traditional litigation process. Given Chief Justice Menon's vision to optimise the coexistence of both litigation and arbitration, the SICC was not established to be a direct competitor with arbitration. For this reason, it is unfair to assess the merits of the SICC by a simplistic comparison with arbitration on the parameters of procedural flexibility and party autonomy.

More importantly, the SICC provides a platform for the innovation and experimentation of procedural reform. Some of the innovations may in due course be adapted for or applied in non-SICC proceedings; they can also serve as a reference template for other jurisdictions interested in embarking upon similar reforms. As such, the SICC and Singapore High Court bifurcation need not be viewed as an immutable 'business class' and 'economy class' treatment of litigants. ${ }^{65}$ But the bifurcation, by reason of the nature of the cases that are to come before the SICC, does emphasise the point that one size does not fit all. ${ }^{66}$

We now consider the unique procedural features of the SICC, each in turn.

\subsubsection{Rules of Evidence}

In SICC proceedings, parties may by agreement apply to the SICC for the disapplication of Singapore rules of evidence $^{67}$ and for other rules of evidence (including rules of evidence that may not constitute part of foreign

64. S. Chong, 'The Singapore International Commercial Court: A New Opening in a Forked Path', 21 October 2015, at para. 5.2, available at: http://www.supremecourt.gov.sg/Data/Editor/Documents/J \%20Steven \% 20Chong \% 20Speeches/The \%20SICC \% 20-\%20A $\% 20$ New $\% 20$ Opening $\% 20$ in $\% 20$ a $\% 2$ Forked $\% 20$ Parth $\% 20$ \%20London\%20(21.10.15).pdf (last visited 8 February 2019).

65. The 'business class' and 'economy class' dichotomy is borrowed from the Right Honorable the Lord Thomas of Cwmgiedd's article, 'Singapore Academy of Law Annual Lecture 2016 - "Cutting the Cloth to Fit the Dispute: Steps towards Better Procedures across the Jurisdictions"' 29 Singapore Academy of Law Journal 1, at 9 (2017).

66. Ibid. For a detailed commentary on and insights into the procedural features of the SICC with illustrations from the first case before the SICC, see H.H. Teh, J. Yeo \& C. Seow, 'The Singapore International Commercial Court in Action: Illustrations from the First Case', 28 Singapore Academy of Law Journal 692 (2016).

67. Section 18K SCJA; Order 110, rule 23(6) Rules of Court. Notably, parties may ask for the disapplication of particular rules or all the rules of evidence under Singapore law. 
law) to be applied instead. ${ }^{68}$ In granting the order, the SICC may, 'for the just, expeditious and economical disposal' of the dispute, modify the parties' agreement with parties' consent or stipulate supplementary terms that are consistent with the parties' agreement as it sees fit. ${ }^{69}$ This procedural feature amply demonstrates the balance between party autonomy and judicial control that the SICC seeks to strike.

The SICC User Guides further explain, using examples, what the outcome might be if Singapore evidence rules are disapplied in the SICC proceedings. ${ }^{70}$ For example, parties may apply to the SICC for the disapplication of the Singapore rule on hearsay without stating which rule should apply in its place. According to the SICC User Guides, if the order is granted, this means that evidence that would otherwise be considered hearsay under Singapore law may be admitted in the proceedings and the issue of reliability of the evidence will be addressed as a matter of the weight of evidence. ${ }^{71}$ It is also useful to note that parties to SICC proceedings may apply for the disapplication of all the rules on evidence under Singapore law and for the IBA Rules on the Taking of Evidence in International Arbitration (IBA Rules), as appropriately adapted, to apply instead. $^{72}$

\subsubsection{Foreign Lam}

Following the convention of common law, foreign law is regarded as an issue of fact under Singapore law. Accordingly, foreign law must be pleaded and proved like facts, ${ }^{73}$ notwithstanding the obvious 'legal quality inherent in this "fact". ${ }^{74}$ As a rule of convenience, if the parties fail to prove the content of the applicable foreign law, Singapore courts will presume the content of foreign law to be identical with Singapore law (referred to as the presumption of similarity of laws), unless 'it is unjust and inconvenient to do so'. ${ }^{75}$

However, the common law mode of proof of foreign law is far from perfect. Reliance on expert evidence, in particular, is expensive, and the expert evidence is at times partisan or even deficient in quality. ${ }^{76}$ Further, the combination of proof and presumption of similarity can lead

Section 18K SCJA read with Order 110, rule 23(1) Rules of Court. An application may not be made unless all parties agree to the rules of evidence that shall not apply to their proceedings, and the rules that shall apply instead.

69. Order 110, rule 23(3) Rules of Court.

70. SICC User Guides Note 4, at paras. 23-5. Seehttps://www.sicc.gov.sg/ docs/default-source/legislation-rules-pd/sicc-user-guides-31jan19.pdf (last visited 10 February 2019).

71. Id., at para. 23

72. Id., at para. 25

73. Foreign law may be proved by 'directly adducing raw sources of foreign law as evidence' or by an expert opinion: see Pacific Recreation Pte Ltd v. S Y Technology Inc [2008] SGCA 1, [2008] 2 SLR(R) 491, at para. 54.

74. EFT Holdings, InC v. Marinteknik Shipbuilders (S) Pte Ltd [2013] SGCA 64, [2014] 1 SLR 860, at para. 57.

75. D'Oz International Pte Ltd v. PSB Corp Pte Ltd [2010] SGHC 88; [2010] 3 SLR 267, at para. 25

76. T.M. Yeo, 'Common Law Innovations in Proving Foreign Law', 12 Yearbook of Private International Law 493, at 493-94 (2010) to 'curious consequences'. ${ }^{77}$ For example, one party may decide to prove the content of some rules of foreign law but not prove the other relevant rules in the hope of relying on the operation of the presumption of similarity, so as to 'mix a cocktail of the two' to arrive at an outcome available under neither legal system. ${ }^{78}$

The SICC framework, while retaining the traditional common law mode of proof, allows for the possibility of dealing with foreign law by way of direct submissions (oral, written or both), ${ }^{79}$ as per the practice in international arbitrations. This reform is strategic, as explained in the SICC Committee Report:

In line with the international character of the SICC, foreign law need not be pleaded and proved as fact in proceedings before the SICC, as the Judges can take judicial notice of foreign law with the assistance of oral and written legal submissions, supported by relevant authorities. The SICC would then apply foreign law to determine the issues in dispute. This pould facilitate buy-in from foreign counsel to bring their disputes to the SICC and, at the same time, aligns SICC procedure with the practice in international arbitration... ${ }^{80}$ (emphasis added)

Importantly, the 'buy-in from foreign counsel' is also forged on other aspects of liberalisation in the SICC framework: the appointment of foreign judges and the greater scope for representation by foreign counsel in SICC proceedings. We will consider these two matters in greater detail in a moment. For present purposes, it suffices to highlight that before ordering the determination of foreign law on the basis of submissions, the SICC must be satisfied that all parties are or will be represented by 'a counsel, ${ }^{81}$ restricted registration foreign lawyer or registered law expert ${ }^{82}$ who is suitable ${ }^{83}$ and competent to submit on the relevant questions of foreign law'. ${ }^{84}$

\subsubsection{Representation by Foreign Lamyers}

As the SICC is a division of the High Court, the general rule is that parties to SICC proceedings are to be represented by lawyers called to the Singapore bar. In traditional High Court proceedings, foreign representation is available in very limited circumstances. Subject to the

77. D. Foxton QC, 'Foreign Law in Domestic Courts', 29 Singapore Academy of Law Journal 194, at 198 (2017).

78. Ibid.

79. Section 18L SCJA; Order 110, rule 25(1) Rules of Court.

80. Report of the Singapore International Commercial Court Committee, above n. 7, at para. 34

81. See Order 110, rule1(1). 'Counsel' includes 'a registered foreign lawyer who is granted full registration under section $36 \mathrm{P}$ of the Legal Profession Act'.

82. See Order 110, rule 1(1). A 'registered law expert' refers to a law expert registered under section 36PA of the Legal Profession Act, ch. 161 (2009) ('LPA'). A registered law expert may appear in SICC proceedings (including appeals) and give advice and prepare documents 'solely for the purposes of making submissions' on matters of foreign law as permitted by the SICC.

83. On showing 'suitability' of the foreign jurist, see Order 110, rule 25(2A) Rules of Court. The SICC may require evidence of good standing.

84. See Order 110, rule 25(2) Rules of Court. 
discretion of the High Court, a foreign lawyer, who is a Queen's Counsel or of equivalent standing, may be granted a right of audience before the High Court on an ad hoc basis. ${ }^{85}$ Considerations that the High Court would need to balance in this discretionary exercise are '(a) nurturing the local Bar; (b) allowing litigants to engage counsel of their choice to advance their case as well as possible; and (c) ensuring the proper and timely administration of justice' 86

In sharp contrast, in SICC proceedings, less restrictive conditions apply in respect of representation by foreign lawyers. ${ }^{87}$ To represent parties in SICC proceedings, foreign lawyers would need to be registered under section 36P of the Legal Profession Act. The SICC foreign lawyer registration regime differentiates between full registration and restricted registration. The type of registration will determine the requisite qualifications of the foreign lawyer as well as the scope of work that the foreign lawyer may undertake on behalf of a party in an SICC case. ${ }^{88}$ In short, only foreign lawyers who have been granted full registration may represent parties in SICC proceedings. Foreign lawyers who have been granted restricted registration may only represent parties for the purposes of making submissions on matters of foreign law as permitted by the SICC or the Court of Appeal. By way of reference, to qualify for full registration, the following criteria must be met: ${ }^{89}$

a. The foreign lawyer is duly authorised or registered to practice law in a foreign jurisdiction.

b. The foreign lawyer has at least 5 years' experience in advocacy before any court or tribunal.

c. The foreign lawyer is sufficiently proficient in English for the purpose of conducting proceedings or appeal.

d. The foreign lawyer has not been disbarred, struck off, suspended, fined, censured or reprimanded in the capacity of a legal practitioner.

e. The foreign lawyer is to give an undertaking that he or she will appear and perform the scope of work that he or she is permitted to undertake on behalf of a party to the SICC proceedings.

At the time of writing this article, seventy-eight foreign lawyers from different jurisdictions have been granted full registration; one English lawyer has been granted restricted registration..$^{90}$

The SICC Practice Directions set out the circumstances under which representation by foreign lawyers in SICC proceedings may be permitted. ${ }^{91}$ The SICC User

85. Section 15 LPA.

86. Re Andrews Geraldine Mary QC [2012] SGHC 229, [2013] 1 SLR 872, at para. 66

87. Section $18 \mathrm{M} \mathrm{SCJA}$

88. See Sections 36P(1) and (2) LPA

89. Rule 4(1) Legal Profession (Foreign Representation in Singapore International Commercial Court) Rules 2014

90. Singapore International Commercial Court, 'Register of Foreign Lawyers,' available at: https://www.sicc.gov.sg/registration-of-foreignlawyers/foreign-lawyers (last visited 8 February 2019).

91. SICC Practice Directions, at para. 26, available at: https:// www.supremecourt.gov.sg/docs/default-source/default-document-
Guides go on to explain that the 'main category of cases' in which foreign representation would be allowed is offshore cases. ${ }^{92}$ As explained previously, ${ }^{93}$ these are cases with no substantial connection to Singapore. Taking a more generous approach in allowing foreign representation in this category of cases may attract foreign counsel to advise their clients to choose the SICC as the dispute resolution forum in cases that are otherwise unlikely to come before the Singapore courts. Conversely, a more restrictive approach towards allowing foreign representation in non-offshore cases protects business for Singapore practitioners and, thus, facilitates buy-in from them to bring their clients' international commercial disputes to the SICC.

\subsubsection{Right of Appeal}

As the SICC is established as a division of the Singapore High Court, SICC cases may be appealed to the Singapore Court of Appeal. However, parties may by writing agree to waive, limit or vary the right to appeal against an SICC judgment. ${ }^{94}$ Instead of mandating a no-appeal litigation model or a traditional litigation model that entails an appeal mechanism, the SICC accords the parties the right to determine for themselves the extent of appeal that they desire. While it may be said that the traditional litigation process enables parties to decide for themselves if they would like to appeal after the trial judge has handed down the judgment and on what issues, the SICC model accords parties the right of determination pre-dispute. Parties may opt for the wholesale exclusion of the right of appeal if they desire a prompt resolution of their dispute and finality of outcome, as per the international commercial arbitration practice.

\subsubsection{Confidentiality}

The default position for SICC cases is open court proceedings and publication of its judgments. Transparency is perceived to be 'important for the branding of the SICC' ${ }^{95}$ The SICC Committee, clearly in recognition of the public interest element in dispute resolution, agreed that confidentiality would '[militate] against the development of a body of jurisprudence, which will be necessary to enable prospective users of SICC dispute resolution to model their future commercial relations' ${ }^{96}$ Nevertheless, parties may apply to the SICC for a confidentiality order under Order 110, rule 30(1) of the Rules of Court, which provides for three different kinds of confidentiality orders: that the case be heard in camera; no disclosure or publication of any information or docu-

library/sicc-practice-directions-(with-effect-from-1jan-2016)f7782f33f22f6eceb9b0ff0000fcc945.pdf.

92. SICC User Guides Note 3, at para. 3. A declaration of 'offshore' status was sought in Teras Offshore Pte Ltd v. Teras Cargo Transport (America) LLC [2016] SGHC(I) 02, [2016] 4 SLR 75 and BNP Paribas SA v. Jacob Agam [2018] SGHC(I) 03 for the purpose of appointing foreign counsel.

93. See text to n. 45 above.

94. SICC Practice Directions, above n. 91, at para. 139.

95. Report of the Singapore International Commercial Court Committee, above n. 7, at para. 32.

96. Ibid 
ment relating to the case; and the sealing of the court order. In deciding whether to grant the confidentiality order sought for, the SICC shall take into account two factors: first, whether the case at hand is an offshore case, and, secondly, whether the parties have agreed to the making of the order. ${ }^{97}$ The SICC User Guides state that 'the [SICC] will generally give due weight to the fact that the case is an offshore case and the parties agree that such an order should be made'. ${ }^{98}$

\subsubsection{Coram}

Every SICC case shall be heard by a single judge or a panel of three judges. ${ }^{99}$ Where the case is to be heard by a panel of three judges, one of the appointed judges shall be appointed by the chief justice to preside over the proceedings. ${ }^{100}$ The case shall be decided in accordance with the majority opinion of the three-judge panel. ${ }^{101}$

Exceptionally, an SICC case may be heard by two judges. ${ }^{102}$ This occurs where one of the three judges originally appointed to decide the case cannot continue in the proceedings and the parties have consented to the proceedings continuing with two judges.

An appeal against an SICC judgment will be heard by the Singapore Court of Appeal. Following the rules applying to Court of Appeal hearings, appeals will be heard by a panel comprising three or 'any greater uneven number of Judges of Appeal'. ${ }^{103}$ An international judge may be appointed by the Chief Justice to sit in the Court of Appeal to hear an appeal against an SICC judgment or order. ${ }^{104}$

\subsubsection{Discovery}

Order 110, rule 21 of the Rules of Court provides that the default position is that the Order 24 procedure that applies in High Court proceedings does not apply in SICC proceedings. ${ }^{105}$ As Thorley IJ noted in B2C2 Ltd v. Quoine Pte Ltd ('B2C2 Ltd'), '[t]here are material differences in language and approach between the discovery provisions in O 110 and O 24'. ${ }^{106}$ Under the SICC regime, the discovery process is referred to as 'production of documents'. The provisions for the SICC regime for production of documents are found in Order 110, rules 14-20 of the Rules of Court.

The traditional process under Order 24 that applies to High Court proceedings requires the parties 'to disclose all documents which are relevant to the issues in the suit, including those of which are or have at any time

97. Order 110, rule 30(2) Rules of Court.

98. SICC User Guides Note 3, at para. 8.

99. Section 18G SCJA.

100. Section $18 \mathrm{H}(2) \mathrm{SCJA}$.

101. Section $18 \mathrm{H}(3) \mathrm{SCJA}$.

102. Section $18 \mathrm{H}(5) \mathrm{SCJA}$. In that event, where the two judges reach different conclusions on the relevant claim, counterclaim or application, the claim, counterclaim or application shall be dismissed (Section $18 \mathrm{H}(6)$ SCJA).

103. Section 30(1) SCJA

104. Section 29(4) SCJA

105. The SICC or the High Court (in the case of a transfer of proceedings to the SICC) may order the application of the Order 24 procedure.

106. [2018] SGHC(I) 04, [2018] 4 SLR 67, at para.15. been in their possession, custody or power'. ${ }^{107}$ For general discovery, parties are to disclose documents on which the parties rely or will rely, as well as documents that could adversely affect his or her own case, adversely affect the case of another party and support another party's case. ${ }^{108}$ In contrast, under the SICC regime, the obligation on parties is more limited - each party is only required to provide 'all documents available to it on which it relies'. ${ }^{109}$ In $B 2 C 2 \mathrm{Ltd}$, Thorley IJ explained that the SICC discovery process

is intended to institute a simplified process compared to [Order 24]. Disclosure is only required of documents that are relevant and material and there is no general discovery. ${ }^{110}$

Relevantly, the SICC provisions on discovery are 'largely' based on the IBA rules. ${ }^{111}$ For example, Order 110 , rule $17(2)(b)$ is based on the wording of Article 9(2) of the IBA Rules. ${ }^{112}$

\subsubsection{Costs}

Costs recovery is an important aspect of litigation. Order 110, rule 46(6) of the Rules of Court makes clear that the SICC regime precludes the application of the Order 59 procedure on taxation of costs by the High Court which applies to traditional High Court proceedings. By way of background, Order 59 provisions are expressed in the terminology of 'costs in in the cause', 'costs in the application', 'costs thrown away', 'costs in any event', 'standard costs', 'indemnity costs' and the like - language which parties from civilian jurisdictions are unaccustomed to. ${ }^{113}$

By contrast, the SICC regime on costs is stated in clear and simple language that may be readily understood by parties from both common law and civil law jurisdictions. Indeed, Vivian Ramsay IJ emphasised in CPIT Investments Ltd v. Qilin World Capital Ltd ${ }^{114}$ that the SICC costs regime is different and simpler than the traditional Order 59 regime. Order 110, rule 46(1), which applies in the SICC, states that:

The unsuccessful party in any application or proceedings in the Court must pay the reasonable costs of the

107. Teh, Yeo \& Seow (2016), above n. 66, at 700.

108. See Order 24, rule (1) and (2) Rules of Court. For specific discovery of documents, see Order 24, rule 5 Rules of Court.

109. Order 110, rule 14(1) Rules of Court. For provisions on request to produce documents, objection to request and application for SICC to order production, see Order 110, rules 15-17 Rules of Court. This process is commonly practised in international arbitration.

110. Id., at para. 32

111. Teh, Yeo \& C. Seow (2016), above n. 66, at 701

112. In B2C2 Ltd, above n. 106, at para. 35, however, Thorley IJ said that case law under discovery regimes in other common law jurisdictions would equally provide guidance on the application of Order 110, rule $17(2)(b)(v)$ Rules of Court.

113. L. Teh, 'Costs Recovery in the SICC, A Different Regime', available at: https://www.sicc.gov.sg/docs/default-source/modules-document/ news-and-article/-costs-recovery-in-the-sicc-a-different-regime-mrlawrence-teh-dentons-rodyk-davidsonIIp_8a224afc-96aa-48c4-8394-7c83ffc3f3bd.pdf (last visited 8 February 2019).

114. [2018] SGHC(I) 2, [2018] 4 SLR 38, at para. 15. 
application or proceedings to the successful party, unless the Court orders otherwise. (emphasis added)

Order 110, rule 46(3) continues to set out the broad discretion which the SICC has in respect of costs orders. Pursuant to the said provision, the SICC may apportion costs between the parties; consider all relevant circumstances (including conduct of the case); order costs to be paid by a lawyer, law expert or a non-party; order interest on costs; or make an ancillary order, including one on time and manner of payment. Supplementing Order 110 , rule 46 of the Rules of Court is the guidance provisions in the SICC Practice Directions on costs. At paragraph 152, the SICC Practice Directions reiterates that costs issues 'shall be in the discretion of the Court and the Court shall have the full power to determine by whom and to what extent the costs are to be paid'. Paragraphs 152(3) and 152(5), in particular, prescribe nonexhaustively the matters which the SICC may take into account in ordering costs.

Notably, the use of wide discretion, the concept of 'reasonable costs' and the principle of the unsuccessful party paying costs are commonly employed in arbitration. 115

\subsection{International Judges}

The SICC panel comprises both local and foreign judges (known as 'International Judges'). ${ }^{116}$ The International Judges are appointed for a fixed term as the chief justice specifies. ${ }^{117}$ The formal power of appointment of International Judges lies with the president of Singapore ${ }^{118}$ and the President of Singapore is to act with the advice of the Prime Minister of Singapore who shall in turn consult the chief justice on the appointment. ${ }^{119}$ There are no legislative provisions on the qualifications of the International Judges. In practice, the matter lies at the discretion of the Chief Justice as he/she is the person to make recommendations for appointment. ${ }^{120}$

The International Judges are assigned by the chief justice to hear SICC disputes on an ad hoc basis. Unlike in arbitrations, there is no scope within the SICC framework for parties to appoint their preferred adjudicator or express a preference for a certain judge to be appointed.

To date, sixteen International Judges have been appointed to the SICC (see table on the next page).

The appointments thus far indicate a trend of favouring the appointment of retired judges. Further, the number

115. See C.Y.C. Ong and M.P. O'Reilly, Costs in International Arbitration (LexisNexis, 2013), at 70-73 (survey of arbitration legislations and procedural rules); The Honourable Sir V. Ramsay, 'Establishing Claims for Damages, Costs and Interest in International Arbitration', 26 American University International Law Review 1211, at 1233-1239 (2011).

116. See Singapore International Commercial Court, 'Judges', available at: https://www.sicc.gov.sg/about-the-sicc/judges (last visited 8 February 2019).

117. See Art. 95(5) Constitution of the Republic of Singapore (1965).

118. Article 95(4) Constitution of the Republic of Singapore.

119. Article 95(6) Constitution of the Republic of Singapore.

120. Article 95(4)(c) Constitution of the Republic of Singapore. of foreign jurists from the UK and Australia appointed as International Judges is significantly higher as compared with jurists from other jurisdictions. This is unsurprising given that English and Australian cases - by reason of common law heritage and legislative influence - are most referred to and followed in Singapore cases, as compared with case law developed in other jurisdictions. ${ }^{121}$ As will be discussed in greater detail in Section 4, many of the SICC cases to date are governed by Singapore law or the relevant applicable foreign law which, in the absence of proof, was presumed to be identical with Singapore law. Given the strong jurisprudential links between Singapore law and English law as well as Australian law, former English and Australian judges are well suited for deciding such disputes and may be (as indeed have been) appointed as sole judges at first instance.

Going forward, it remains to be seen if more jurists from Asian jurisdictions will be appointed to the SICC, in view that a primary aim of the SICC is to become the leading Asian dispute resolution centre. Casting a sideway glance at the SIAC's panel of arbitrators, while there are many Australian and UK arbitrators, the SIAC panel also boasts arbitrators from many Asian jurisdictions, including India, Philippines, Indonesia, Korea, China and Malaysia. ${ }^{122}$

\section{Review of SICC Judgments}

At the date of writing, a total of thirty-four SICC judgments, comprising both procedural orders and judgments on the merits of the disputes, have been handed down. Of course, a number of the orders and judgments pertain to (different aspects of) the same cases. Of the thirty-four judgments, seven were appellate judgments rendered by the Singapore Court of Appeal. All thirtyfour judgments related to cases transferred from the Singapore High Court to the SICC. ${ }^{123}$ This is unsurprising. In the initial years of the SICC's operation, many potential users of the SICC are likely to take a 'wait and see' approach, generally resistant to the idea to be the first ones to try out something new and untested. Moreover, even if parties are willing to insert an SICC clause into their contract, it will be some time before a dispute arises. In February 2018, marking an important milestone for the SICC, a case was directly filed with the SICC. While we wait for more cases to be filed directly with the SICC on the basis of an SICC clause, the transfer cases would play a crucial role in establishing the initial track record for the SICC. For this rea-

121. See Y.H. Goh and P. Tan, 'The Development of Local Jurisprudence', in Y.H. Goh and P. Tan (gen. eds.), Singapore Law: 50 Years in the Making (2015) 195, at 222-35.

122. See Singapore International Arbitration Centre, Our Arbitrators, available at: http://siac.org.sg/our-arbitrators/siac-panel (last visited 8 February 2019).

123. What is unclear is how many of the cases were non-consensual transfers. 


\begin{tabular}{|c|c|c|c|c|}
\hline No. & International judge & Home jurisdiction & Appointment & $\begin{array}{l}\text { Professional experience } \\
\text { (in brief) }^{121}\end{array}$ \\
\hline 1. & Justice Patricia Bergin & Australia & January 2015-present & $\begin{array}{l}\text { Former Judge of the Supreme } \\
\text { Court of New South Wales (retired } \\
\text { in 2017) }\end{array}$ \\
\hline 2. & Justice Roger Giles & Australia & January 2015-present & $\begin{array}{l}\text { Former Judge of the Court of } \\
\text { Appeal of New South Wales } \\
\text { (retired in 2011) }\end{array}$ \\
\hline 3. & Justice Dyson Heydon AC QC & Australia & January 2015-present & $\begin{array}{l}\text { Former Judge of the High Court of } \\
\text { Australia (retired in 2013); current- } \\
\text { ly barrister and arbitrator }\end{array}$ \\
\hline 4. & Justice Robert French & Australia & January 2018-present & $\begin{array}{l}\text { Former Chief Justice of Australia } \\
\text { (retired in 2017); non-permanent } \\
\text { Judge in the Hong Kong Court of } \\
\text { Final Appeal }\end{array}$ \\
\hline 5. & Justice Irmgard Griss & Austria & $\begin{array}{l}\text { January 2015-January } \\
2018\end{array}$ & $\begin{array}{l}\text { Former president of the Austrian } \\
\text { Supreme Court }\end{array}$ \\
\hline 6. & Justice Beverley McLachlin PC & Canada & January 2018-present & $\begin{array}{l}\text { Former Chief Justice of Canada } \\
\text { (retired in 2017) }\end{array}$ \\
\hline 7. & Justice Dominique T. Hascher & France & January 2015-present & $\begin{array}{l}\text { Judge of Supreme Judicial Court of } \\
\text { France }\end{array}$ \\
\hline 8. & Justice Anselmo Reyes & Hong Kong & January 2015-present & $\begin{array}{l}\text { Former Judge of the Court of First } \\
\text { Instance in Hong Kong (retired in } \\
\text { 2012) }\end{array}$ \\
\hline 9. & Justice Yasuhei Taniguchi & Japan & January 2015-present & $\begin{array}{l}\text { Professor Emeritus at Kyoto Uni- } \\
\text { versity, Japan; former Chairperson } \\
\text { of the appellate body of WTO }\end{array}$ \\
\hline 10. & Justice Sir Vivian Ramsey & UK & January 2015-present & $\begin{array}{l}\text { Former Judge of the High Court } \\
\text { (Queen's Bench Division) of Eng- } \\
\text { land and Wales (retired in 2014) }\end{array}$ \\
\hline 11. & Justice Sir Bernard Rix & UK & January 2015-present & $\begin{array}{l}\text { Former Lord Justice of Appeal in } \\
\text { the Court of Appeal of England } \\
\text { and Wales (retired in 2013) }\end{array}$ \\
\hline 12. & Justice Simon Thorley QC & UK & January 2015-present & $\begin{array}{l}\text { Former barrister specialising in } \\
\text { intellectual property (retired in } \\
\text { 2014); former Deputy High Court } \\
\text { Judge of England and Wales }\end{array}$ \\
\hline 13. & Justice Sir Henry Bernard Eder & UK & May 2015-present & $\begin{array}{l}\text { Former Judge of the High Court of } \\
\text { England and Wales (retired in } \\
\text { 2015) }\end{array}$ \\
\hline 14. & $\begin{array}{l}\text { Justice David Edmond } \\
\text { Neuberger }\end{array}$ & UK & January 2018-present & $\begin{array}{l}\text { Former President of the UK } \\
\text { Supreme Court (retired in 2017) }\end{array}$ \\
\hline 15. & Justice Jeremy Cooke & UK & January 2018-present & $\begin{array}{l}\text { Former Judge of the High Court of } \\
\text { England and Wales (retired in } \\
\text { 2016); current international judge } \\
\text { of the DIFCC }\end{array}$ \\
\hline 16. & Justice Carolyn Berger & US & January 2015-present & $\begin{array}{l}\text { Former Justice on the Delaware } \\
\text { Supreme Court (retired in 2014) }\end{array}$ \\
\hline
\end{tabular}

121 Information is based on the international judges' biographies on the SICC website: see Singapore International Commercial Court, above n. 116. 
son, the last part of the discussion reviews the SICC judgments.

\subsection{Profile of Cases}

By way of a quick overview, the following is a summary of the profile of SICC cases decided to date:

a. In all cases, at least one of the parties was based in an Asian jurisdiction.

b. In all cases, the party and event connections of the dispute were distributed across at least two different jurisdictions.

c. The substantive legal issues that have been raised include contract, ${ }^{124}$ tort, ${ }^{125}$ trust, ${ }^{126}$ fiduciary duties, directors' duties and minority oppression.

d. Most of the cases involved Singapore law as the governing law of the issues in dispute. ${ }^{127}$ Two matters raised issues governed by French law. ${ }^{128}$ One matter involved issues governed by English law. ${ }^{129}$ One matter involved Bahamas law as the governing law but the parties agreed that the content of Bahamas law did not differ from Singapore law. ${ }^{130}$ One matter raised an issue governed by Indonesian law. ${ }^{131}$

\subsection{Assignment of International Judges}

Based on a review of the SICC judgments handed down to date, it is clear that the international judges - touted as a distinctive capability of the SICC - have been actively deployed to hear the cases brought before the SICC by way of exercise of transfer jurisdiction. They have been appointed as either a single judge or a mem-

ber of a three-judge panel to hear SICC appeals, trials and procedural/interlocutory matters. When appointed as a member of a three-judge panel, ${ }^{132}$ the international judges had also taken on the responsibility to deliver the judgment of the court in a number of cases. ${ }^{133}$ Further, in all appeal hearings, at least one member of the threejudge panel was an international judge. ${ }^{134}$

124. A wide range of contractual issues have been discussed, including interpretation, breach, contract formation, misrepresentation and mistake.

125. For example, tort of conspiracy, tort of inducing breach of contract, and tort of conversion.

126. For example, constructive trust and equitable compensation for breach of trust.

127. This is unsurprising as these are cases transferred from the High Court to the SICC.

128. See BNP Paribas Wealth Management v. Jacob Agam [2017] SGHC(I) 02, [2017] 4 SLR 14 (concept of subrogation under French law); BNP Paribas SA v. Jacob Agam [2017] SGHC(I) 10, [2018] 3 SLR 1 (The French law issues were later abandoned.).

129. Macquarie Bank Ltd v. Graceland Industry Pte Ltd [2018] SGHC(I) 05, [2018] 4 SLR 87.

130. Telemedia Pacific Group Limited v. Yuanta Asset Management International Limited [2016] SGHC(I) 03, [2016] 5 SLR 1 (Patricia Bergin IJ was appointed as a single judge in the case.).

131. BCBC Singapore Pte Ltd v. PT Bayan Resources TBK [2016] SGHC(I) 01, [2016] 4 SLR 1, at paras. 181-228.

132. As a matter of general practice, at least one Singapore judge is included in a three-member panel.

133. See, e.g. Arris Solutions Inc v. Asian Broadcasting Network (M) Sdn Bhd [2017] SGHC(I) 01, [2017] 4 SLR 1 (Judgment was delivered by Simon Thorley IJ.).

134. See, e.g. BNP Paribas SA v. Jacob Agam [2018] SGCA(I) 07 (Judgment was delivered by David Edmond Neuberger IJ.).
In the two matters which had connections with France and in which French issues were raised, Dominique Hascher IJ was appointed as a member of the threejudge panel. ${ }^{135}$ In the matter in which issues governed by English law were raised, Sir Henry Bernard Eder IJ was appointed as the sole judge. ${ }^{136}$ Interestingly, international judges from the UK and Australia have been appointed as a single judge to hear cases which involved issues governed by Singapore law ${ }^{137}$ or where the matter raised issues of Singapore procedural law. ${ }^{138}$ In these disputes concerning Singapore law as the applicable law, it is evident from the judgments that the presiding international judge ensured that relevant Singapore cases were cited and discussed.

In light of the foregoing review, one could surmise that the Singapore judiciary is unafraid of allowing foreign jurists to directly participate in the application and development of Singapore law. As the SICC is a division of the High Court, its judgments on Singapore law are binding authorities on the High Court.

A number of interesting questions may be asked in the future when there is a sizeable pool of SICC judgments on Singapore law for a more in-depth study. First, whether the development of Singapore law in the SICC has proceeded on a more transnational (and less English law-biased) trajectory, with the participation of non-UK international judges. ${ }^{139}$ Indeed, a similar question may be asked in respect of the development of commercial law in general in the SICC. Second, whether the creation of the SICC has led to a two-track development of Singapore law: one in the SICC and one in the High Court. For example, the SICC judges, being aware of their capacity as a judge in an international commercial court, might be more inclined towards applying 'hard and fast rules' and 'fixed' criteria, as opposed to discretionary approaches. ${ }^{140}$ Third, whether the international judges are adept at grappling with questions of Singapore public policy? Fourth, whether the presence of international judges would enhance the global influence of the SICC judgments? For example, these judgments may be more persuasive or more frequently referred to

135. See, BNP Paribas Wealth Management v. Jacob Agam [2017] SGHC(I) 02, [2017] 4 SLR 14; BNP Paribas SA v. Jacob Agam [2017] SGHC(I) 10, [2018] 3 SLR 1.

136. See Macquarie Bank Ltd, above n. 129.

137. See, e.g. Telemedia Pacific Group, above n. 130 (Parties have agreed that the content of applicable foreign law is identical to that of Singapore law and proceeded on that basis); CPIT Investments Ltd v. Qilin World Capital Ltd [2017] SGHC(I) 05, [2017] 5 SLR 1 (Vivian Ramsay IJ).

138. See, e.g., Macquarie Bank Ltd v. Graceland Industry Pte Ltd [2017] SGHC(I) 12 (Henry Bernard Eder IJ); Arovin Ltd v. Hadiran Sridjaja [2018] SGHC(I) 09, (Vivian Ramsay IJ). To be clear, these two judgments ruled on issues concerning general Singapore procedural law that is also applicable to traditional High Court proceedings, as opposed to procedural rules that are unique to the SICC regime.

139. See Telemedia Pacific Group, above n. 130. Bergin IJ, an Australian international judge, cited a number of Australian authorities in support of trite contractual principles.

140. See CPIT Investments Ltd v. Qilin World Capital Ltd, above n. 137, at para. 199, where Vivian Ramsey IJ suggested that under Singapore law (as with any other legal system), a remedial constructive trust is 'imposed sparingly'. 
by the courts of the home jurisdictions of the international judges.

\section{Challenges Ahead}

We now consider the challenges confronting the SICC going forward.

\subsection{Competition from CICC?}

To provide a judicial safeguard for the BRI, on 29 June 2018, China established the CICC to serve the dispute needs of the BRI. Presently, the Supreme People's Court of China (SPC), in charge of the creation of the CICC, is 'in the final stages of formalising its rules and procedures'.141 A judicial interpretation document issued by the SPC, entitled 'Provisions of the Supreme People's Court on Several Issues Regarding the Establishment of the International Commercial Courts' sets out the CICC framework, the jurisdiction of its courts, judicial panel and numerous procedural provisions (the 'Judicial Interpretation on the CICC'). ${ }^{142}$ The creation of the CICC may raise some concern as to whether it would compete for judicial business with the SICC. ${ }^{143}$

A review of the CICC framework deserves detailed treatment in a separate article. ${ }^{144}$ It suffices, for present purposes, to highlight the main competitive advantages which the SICC has over the CICC. It is argued that the SICC is a far more attractive litigation option than the CICC.

First, unlike the SICC, the CICC's jurisdictional framework is much more constrained. Notably, a written jurisdiction agreement in favour of the CICC is insuffi-

141. M. Walters, 'Jury Is Out Over China's New Commercial Court, Say Lawyers', UK Law Gazette, 1 November 2018, available at: https:// www.lawgazette.co.uk/law/jury-is-out-over-chinas-new-commercialcourt-saylawyers/5068125.article?

utm_source=dispatch\&utm_medium=email\&utm_campaign= \%20GAZ141016 (last visited 8 February 2019).

142. 'Provisions of the Supreme People's Court on Several Issues Regarding the Establishment of the International Commercial Court' (Court Explanation No 11 of 2018)] (promulgated by the Supreme People's Court on 27 June 2018; effective as on 1 July 2018), available at: http://www.court.gov.cn/zixun-xiangqing-104602.html? (last visited 8 February 2019).

143. The CICC has announced on 29 December 2018 that it has accepted 'a number of international commercial disputes in accordance with Article 20 and Article 38 of the Civil Procedure Law of the People's Republic of China and Article 2 of the Provisions of the Supreme People's Court on Several Issues Regarding the Establishment of the International Commercial Court'. Based on the information, it may be surmised that these are transfer cases. See http://cicc.court.gov.cn/html/1/219/208/210/ 1152.html (last visited 8 February 2019).

144. See W. Sun, 'International Commercial Court in China: Innovations, Misunderstandings and Clarifications', Kluwer Arbitration Blog, 4 July 2018, available at: http://arbitrationblog.kluwerarbitration.com/ 2018/07/04/international-commercial-court-china-innovationsmisunderstandings-clarifications/ (last visited 8 February 2019); 'With An Eye on Belt and Road Disputes, China Establishes New International Commercial Courts', Herbert Smith Freehills, 4 July 2018, available at: https://www.herbertsmithfreehills.com/latest-thinking/with-an-eye-onbelt-and-road-disputes-china-establishes-new-international-commercial (last visited 8 February 2019); Z. Huo and M. Yip, (2019, forthcoming), above n. 11. cient by itself to establish the CICC's jurisdiction over a dispute, unless the amount in dispute exceeds RMB 300 million and the case has an actual connection with China. ${ }^{145}$ As such, party autonomy is clearly less valued within the CICC's jurisdictional framework, as compared with the SICC regime.

Second, the CICC judges are Chinese judges drawn from the SPC. ${ }^{146}$ Currently, fifteen SPC judges have been appointed to the CICC. ${ }^{147}$ Chinese law (Judges' Law and the Law on the Organisation of the People's Courts) does not permit the appointment of foreigners as judges of the Chinese courts. The absence of an international bench may affect user confidence in the impartiality and trustworthiness of the CICC, especially because the CICC disputes will likely involve at least one non-Chinese party. Further, it is envisaged that many of the disputes arising from the BRI would involve foreign law elements. An international bench (such as the SICC panel) would boost greater confidence in the more accurate interpretation and application of foreign law, where there are foreign judges on the bench who are trained in the relevant foreign law. The decision to appoint only Chinese nationals as CICC judges reflects a strong desire for ensuring forum control in the dispute resolution process. Perhaps, this shortcoming of the CICC could be mitigated to some extent by the establishment of the CICC's International Commercial Expert Committee. To date, thirty-two experts from different countries have been appointed. ${ }^{148}$ However, the precise remit of the Expert Committee remains unclear, and its utility cannot, thus, be fully assessed at this point.

Third, current Chinese law does not grant foreign lawyers a right of audience before the Chinese courts (including the CICC). ${ }^{149}$ This limitation diminishes the CICC's appeal to the international business community who are very much used to the procedural flexibility of arbitration practice. Indeed, in cases which raise foreign law issues, litigants (especially non-Chinese nationals) would likely prefer to engage foreign counsel who are familiar with the relevant foreign law.

Finally, pursuant to existing Chinese legislation, proceedings of cases involving foreign elements must be conducted in 'languages commonly used in China' - in other words, in Chinese or the native languages of the

145. Judicial Interpretation on the CICC, above n. 143, Art. 2.

146. On the basic qualifications of CICC judges, see Judicial Interpretation on the CICC, above n. 143, Art. 4

147. See China International Commercial Court, available at: http:// cicc.court.gov.cn/html/1/219/193/196/index.html (last visited 8 February 2019).

148. See 'The Decision on Appointment of the First Group of Members for the International Commercial Expert Committee', China International Commercial Court, 24 August 2018, available at: http:// cicc.court.gov.cn/html/1/219/235/245/index.html (last visited 8 February 2019). This first group of experts have been appointed for a fouryear term, from 26 August 2018 to 26 August 2022.

149. Civil Procedure Law (promulgated by the President of the People's Republic of China on 9 April 1991) and the Law on the Organisation of the People's Courts (promulgated by the Chairman of the Standing Committee of the National People's Congress on 5 July 1979; effective as on 1 July 1980). 
fifty-five officially recognised ethnic minorities in China. ${ }^{150}$ This creates an unnecessary language barrier for foreign litigants. Moreover, it is unclear why the language of proceedings before the CICC - an international commercial court - does not include English, given that litigants from the BRI countries would speak a variety of languages and that the prescribed qualifications of the CICC judges include the ability to use English as a working language. ${ }^{151}$

\subsection{International Enforceability of Singapore Judgments}

The real challenge for the SICC concerns the international enforceability of Singapore judgments. Practically speaking, users of the SICC (or any international commercial court for that matter) would be most concerned with whether the judgments may be recognised and enforced in other jurisdictions, most notably, where the assets of the judgment debtor are located. Enforceability of outcomes is the key reason why business parties favour international commercial arbitrations. ${ }^{152}$ As Godwin, Ramsay and Webster have astutely observed, 'the problem of enforcement is more acute for international commercial courts as "the parties before such courts may have little or no presence and few (if any) assets within the state where the courts are located"'. ${ }^{153}$ Hence, in 2016, Singapore has signed and ratified the Hague Convention which prescribes rules for both jurisdiction and the recognition and enforcement of judgments. ${ }^{154}$ The Hague Convention regime applies in 'international cases to exclusive choice of court agreements concluded in civil or commercial matters'. ${ }^{155}$ One of the basic rules under the Hague Convention is that a judgment by the chosen court must be recognised or enforced in Contracting States, ${ }^{156}$ subject to limited exceptions set out in Article 9. At the date of writing, the Hague Convention has entered into force in Mexico, Montenegro and the European Union member states (including Denmark). China, the USA and Ukraine have signed but yet to ratify the Hague Convention. ${ }^{157}$ Where there is no treaty arrangement in place, a Singapore judgment may be recognised and enforced in accordance with the domestic rules of the recognising/ enforcing jurisdiction. ${ }^{158}$ However, this domestic rule

150. Civil Procedural Law, Art. 11

151. Judicial Interpretation on the CICC, above n. 143, Art. 4

152. See discussion in text to nn. 13-15 above.

153. A. Godwin, I. Ramsay \& M. Webster, 'International Commercial Courts: The Singapore Experience', 18 Melbourne Journal of International Law 219 , at 233 (2017).

154. The local implementing legislation is the Choice of Court Agreements Act, ch. 39A (2016)

155. Hague Convention, Art. 1(1)

156. Hague Convention, Art. 8.

157. See Status Table, available at: https://www.hcch.net/en/instruments/ conventions/status-table/?cid=98 (last visited 8 February 2019). Although Canada has not ratified the Hague Convention, Ontario has recently enacted the International Choice of Court Agreements Convention Act 2017 to give effect to the Hague Convention in anticipation of Canada's ratification.

158. For more details, see discussion in 'Report of the Law Reform Committee on Enforcement of Enforcement of Foreign Judgments' Singapore Academy of Law, Law Reform Committee (June 2005), at pp. 8-9, avenue is far more uncertain, as the requirements and their application would vary from jurisdiction to jurisdiction. ${ }^{159}$ Indeed, it has been observed that it is very difficult to recognise or enforce foreign judgments in some ASEAN countries. ${ }^{160}$

To increase the portability of its judgments abroad, Singapore continues to seek ways, directly or indirectly, to foster collaboration and trust with the courts of other countries. The Supreme Court of Singapore, on 19 January 2015, entered into a non-binding 'Memorandum of Guidance' with the DIFC Courts concerning the reciprocal enforcement of money judgments. ${ }^{161}$ On 31 August 2018, the Supreme Court of Singapore entered into a Memorandum of Guidance with the SPC on the recognition and enforcement of money judgment in commercial cases. ${ }^{162}$ The Asian Business Law Institute is now undertaking a project on the harmonisation of the rules of recognition and enforcement of foreign judgments in Asia. The first phase of the project concerning the description of domestic rules in each Asian jurisdiction has been completed and published. ${ }^{163}$ It is hoped that these efforts will bring forth comprehensive reciprocal treaty arrangements in the future.

\section{Conclusion}

The SICC framework of litigation is undergirded by the values of hybridisation (between litigation and arbitration), internationalisation (participation by foreign lawyers and judges) and party autonomy. It changes our frame of reference for what international commercial litigation should be like. It helps to establish the norm that litigation can be neutral, effective and user focused. This is Singapore's contribution to the future of dispute resolution.

Going forward, the SICC will need to build its docket on the basis of cases arising out of an SICC clause and not continue to be heavily reliant on transfer cases. How soon this may be achieved would depend on the compe-

available at: https://www.sal.org.sg/Portals/0/PDF\%20Files/Law \%20Reform/2005-06\%20-\%20Enforcement\%20of\%20Foreign \%20Judgments.pdf (last visited 8 February 2019).

159. For common law countries, the requirements for enforcement of foreign judgments are largely similarly to the requirements under Singapore law.

160. For example, Thailand and Indonesia. See Hsu, Koh \& Yip (2018), above n. 9

161. See Supreme Court of Singapore and DIFC Courts, 'Memorandum of Guidance as to Enforcement Between the Supreme Court of Singapore and the Dubai International Financial Centre Courts', 2015, available at: https://www.supremecourt.gov.sg/docs/default-source/defaultdocument-library/dubai-mog-2015-cj-menon-and-cj-of-difc(memorandum-of-guidance)4bb63033f22f6eceb9b0ff0000fcc945.pdf (last visited 8 February 2019).

162. See H. Baharudin, 'Singapore and China Courts Agree on Guide for Money Judgement in Commercial Cases to Be Recognised in Each Other's Countries', The Straits Times, 3 September 2018, available at: https://www.straitstimes.com/singapore/singapore-and-china-courtsagree-on-guide-for-money-judgment-in-commercial-cases-to-be (last visited 8 February 2019).

163. A. Chong (ed.), Recognition and Enforcement of Foreign Judgments in Asia, ABLI Legal Convergence Series (2017). 
tition from other dispute resolution institutions, the degree of the international enforceability of the SICC judgments, and the willingness of lawyers and in-house counsel to insert SICC clauses into commercial contracts.

More interestingly, the mid- to long-term impact of the SICC, domestically and internationally, merits an indepth study in due course. Section 4 highlights questions concerning the impact of foreign judges on the development and influence of Singapore law. But there are other equally interesting facets to consider, for instance, whether other international commercial courts would base their design on the SICC or adopt successful procedural reforms from the SICC. This will be a measure of SICC's influence on the design of dispute resolution mechanisms. Further, what is the impact of the liberalisation of the criteria for foreign lawyers to appear as counsel in SICC proceedings? Does this reform bring in more dispute business for Singapore? How do local lawyers support litigation in which foreign lawyers appear as counsel, and do these interactions inspire healthy competition and better litigation practices? We await the full impact of the SICC. 